\section{Michigan Technological \\ 18 8 5 University}

Michigan Technological University Digital Commons @ Michigan Tech

Global Conference of the Youth Environmental

Alliance in Higher Education

Apr 21st, 1:25 PM - 1:34 PM

\title{
Session 1D Conservation of the Pygmy sloth, Bradypus pygmaeus
}

Paige Copcutt

University of Derby

Follow this and additional works at: https://digitalcommons.mtu.edu/yeah-conference

\section{Recommended Citation}

Copcutt, Paige, "Session 1D Conservation of the Pygmy sloth, Bradypus pygmaeus" (2021). Global Conference of the Youth Environmental Alliance in Higher Education. 17.

https://doi.org/10.37099/mtu.dc.yeah-conference/april2021/all-events/17 
